\title{
Doxorubicin and etoposide sensitize small cell lung carcinoma cells expressing caspase-8 to TRAIL
}

\author{
Alena Vaculova ${ }^{\dagger}, V$ italiy Kaminskyy ${ }^{\dagger}$ Elham Jalalvand, Olga Surova and Boris Zhivotovsky*
}

\begin{abstract}
Background: TRAIL is considered as a promising anti-cancer agent, because of its ability to induce apoptosis in cancer but not in most normal cells. However, growing evidence exist that many cancer cells are resistant to its apoptotic effects. SCLC is a typical example of tumor entity where TRAIL monotherapy is not efficient.

Results: We demonstrated that doxorubicin and etoposide markedly sensitized SCLC cells expressing caspase-8 to apoptotic effects of TRAIL. The drug-mediated sensitization of these cells was associated with increase of surface and total DR5 protein level, specific cleavage of CFLIP, decrease of CFLIP ${ }_{S}$ level, and a strong activation of caspase-8. The involvement of mitochondria-mediated pathway was demonstrated by enhanced Bid cleavage, Bax activation, and cytochrome $c$ release. Activation of caspase- 8 induced by combined treatment was shown to occur upstream of mitochondria and effector caspases.
\end{abstract}

Conclusions: Our results highlight significant applicability of doxorubicin and etoposide in sensitization of SCLC cells expressing caspase-8 to treatment with TRAIL.

\section{Background}

Lung cancer (LC) is a major cause of cancer deaths in the Western world. Based on the histo-pathological features, LC is divided into small cell lung carcinoma (SCLC), and non-small cell lung carcinoma (NSCLC), which account for 25 and $75 \%$ of bronchogenic carcinomas, respectively. In contrast to NSCLC, SCLC is characterized by relatively high sensitivity to treatment with anticancer drugs and radiation. However, despite the initial responsiveness, relapses occur in most cases, accompanied by the fast development of severe resistance to treatments during the course of disease. SCLC represents a highly malignant and particularly aggressive form of cancer, with early and widespread metastases, and poor prognosis. Mechanisms responsible for the intrinsic and acquired resistance to treatment involve the defects/dysregulations of the apoptotic programme [1,2]. The avoidance of apoptosis is considered as one of the hallmarks of cancer cells, and represents a significant clinical problem. Therefore, elucidation of the mechanisms and molecules responsible

\footnotetext{
* Correspondence: Boris.Zhivotovsky@ki.se

1 Institute of Environmental Medicine, Division of Toxicology, Karolinska

Institutet, Box 210, SE-171 77 Stockholm, Sweden

+ Contributed equally

Full list of author information is available at the end of the article
}

for the resistance is essential for proper targeting of anticancer therapy.

The tumour necrosis factor (TNF)-related apoptosisinducing ligand (TRAIL), a member of TNF family, is particularly interesting because of its unique ability to induce cancer cell death while sparing the most of normal cells. This implies its potential promise as an anti-cancer agent [3]. TRAIL can interact with different receptors. Only two of them, namely, death receptors (DR) contain apoptosis-related death domain (DD): DR4 (TRAIL-R1) and DR5 (TRAIL-R2). Decoy receptors DcR1 (TRAILR3) and DcR2 (TRAIL-R4) either lack or posses truncated DD and are, therefore, not able to transmit apoptotic signal. Osteoprotegerin (OPG, TRAIL-R5) is a soluble receptor with the lowest afinity to TRAIL [4]. TRAIL binding to DR4 and DR5 results in triggering of the extrinsic pathway, initiated by formation of the deathinducing signalling complex (DISC) consisting of Fasassociated DD protein (FADD) and pro-caspase-8. Activation of caspase- 8 at the DISC level plays a crucial role in the DR-mediated pathway, and can be efficiently regulated by its competitive inhibitor cFLIP (FLICE-like inhibitory protein). Caspase- 8 activation is followed by cleavage of effector caspases and apoptosis execution (characteristic for type I cells). In some cases, caspase-8 
can also cleave Bid, which is responsible for translocation of apoptotic signal to mitochondria. Subsequent amplification of the death signal at the level of these organelles is essential in so-called type II cells $[5,6]$.

TRAIL triggers apoptosis in a broad spectrum of cancer cell lines in vitro and in vivo $[7,8]$. However, failure to undergo apoptosis in response to TRAIL has been demonstrated in majority of SCLC cells $[9,10]$. Significant perturbances of apoptosis programme such as downregulation/absence of some proapoptotic proteins and/or overexpression of anti-apoptotic proteins have been shown to be a characteristic feature of SCLC cells [11]. The higher rates of loss of expression of caspase-8, caspase-10, DR4, DR5, Fas, and FasL have been found in SCLC compared to NSCLC cells $[9,12]$. A relationship between the inactivation of some DISC components and Myc oncogene amplification, which is a common event in SCLC, has also been reported [9].

Majority of chemotherapeutic agents are typical activators of mitochondria-mediated (intrinsic) apoptotic pathway, where release of cytochrome $c$ from mitochondrial intermembrane space is followed by formation of apoptosome complex (cytochrome $c$, Apaf- 1 , dATP, pro-caspase-9), activation of initiator caspase- 9 and downstream effector caspases. The described events can be effectively modulated by pro-apoptotic (e.g. Bid, Bax, Bak) and/or anti-apoptotic (e.g. Bcl-2, Mcl-1, Bcl- $\mathrm{X}_{\mathrm{L}}$ ) members of Bcl2 family [13]. Caspase- 2 has been shown as an important link between DNA damage and the engagement of the mitochondrial pathway [14].

The clinically relevant concentrations of chemotherapeutic drugs might restore the apoptotic response to TRAIL in various cancer cells through different mechanisms and, therefore, sensitize these cells to TRAIL treatment. Among them, upregulation of the DRs, facilitation of DISC formation, downregulation of anti-apoptotic proteins, enhancement of activation of mitochondrial pathway and caspase cascade are particularly interesting $[15,16]$. However, respective data concerning SCLC treatments are still missing. The usual therapeutic regimes used for this type of cancer include e.g. doxorubicin, etoposide or cisplatin. As TRAIL monotherapy has been shown to be ineffective in SCLC, in present study we explored the potential use of combination of TRAIL and doxorubicin or etoposide in order to provide a tool for triggering apoptosis in resistant cancer cells.

\section{Materials and methods \\ Cell culture and treatments}

Human SCLC cell lines - H69 (ECACC), H82 (ATCC), U1285, U1690, and U1906 [17] were grown in RPMI 1640 medium supplemented with $10 \%$ of heat-inactivated fetal bovine serum (FBS), glutamine (2 mM), penicillin (100 U/ $\mathrm{ml})$ and streptomycin $(100 \mu \mathrm{g} / \mathrm{ml})$ (all from Gibco) in $37^{\circ} \mathrm{C}, 5 \% \mathrm{CO}_{2}$ and $95 \%$ humidity. Twenty-four hours after seeding, cells were treated with human recombinant Killer TRAIL (provided by Dr. L. Andera), doxorubicin (Sigma), etoposide (Vepesid, Bristol-Myers), PKC412 (CGP41251, Novartis), cycloheximide (Sigma), pan-caspase inhibitor z-VAD-fmk (Enzyme Systems Products) or vehicle (DMSO) for the time points and concentrations indicated in figure legends.

\section{Surface TRAIL receptor expression}

The level of surface TRAIL receptors was detected in cells after incubation with specific antibodies using flow cytometry [18]. Briefly, after washing with PBS + 5\% FBS, cells were incubated $\left(20\right.$ minutes, $\left.4^{\circ} \mathrm{C}\right)$ with primary antibody (anti-TRAIL-R1 to -4 flow cytometry set, Axorra; HS101, HS201, HS301, HS402 antibodies, respectively). Cells were then washed twice, and incubated $(20 \mathrm{~min}$, $4^{\circ} \mathrm{C}$ ) with secondary antibody (FITC-conjugated goat anti-mouse IgG1, ALX-211-200, Axorra or AlexaFluor488-conjugated donkey anti-mouse-IgG, A21202, Molecular Probes). After washing twice, the cells were stained (15 min, $\left.4^{\circ} \mathrm{C}\right)$ with 7 -AAD $(1 \mu \mathrm{g} / \mathrm{ml}$, Molecular Probes) and analyzed using flow cytometry (FACScan, Becton Dickinson). The 7-AAD negative cells were subjected to receptor analysis (Cell Quest software). Results are expressed as histograms (green fluorescence indicating the amount of the receptor present at the cell surface versus cell counts), and related to appropriate control lacking the specific primary antibody.

\section{Analysis of Bax activation}

Cells were washed in PBS, fixed in 1\% paraformaldehyde $\left(10\right.$ minutes, $\left.4^{\circ} \mathrm{C}\right)$, washed again, and incubated $(30 \mathrm{~min}$, $4^{\circ} \mathrm{C}$ ) with mouse anti-Bax antibody (BD556467, Becton Dickinson) diluted in PBS containing 1\% BSA and 0.1\% saponin. After additional washing, cells were incubated $\left(30 \mathrm{~min}, 4^{\circ} \mathrm{C}\right.$ ) with AlexaFluor-488-conjugated donkey anti-mouse IgG secondary antibody (A21202, Molecular Probes) diluted in PBS + 1\% BSA + 0.1\% saponin, washed twice, and resuspended in PBS. For each sample, controls lacking the specific primary antibody were prepared. Analysis was performed using flow cytometer (FACScan, Becton Dickinson) and CellQuest software. Ten thousand cells per sample were analysed and the results were expressed as percentage of cells with active Bax.

\section{Analysis of mitochondrial membrane potential (MMP)}

After washing in PBS, cells were incubated (20 minutes) in HBSS with $25 \mathrm{nM}$ of tetramethylrhodamine ethyl ester perchlorate (TMRE, Molecular Probes), washed twice with HBSS, and analysed $\left(2 \times 10^{4}\right.$ cells per sample) by flow cytometry (FACScan, Becton Dickinson). Forward and side scatters were used to gate the viable cell popula- 
tion. The data were evaluated using Cell Quest software as a percentage of the cells with decreased MMP.

\section{Caspase activity assay}

Cells were lysed in appropriate lysis buffer, incubated with caspase-3, caspase- 8 or caspase- 2 substrates and analysed as described previously [19]. The values of caspase activity were related to the total protein amount. Caspase activity was expressed as a fold-increase to appropriate control.

\section{Immunoblotting}

Cells were lysed in Complete lysis buffer (Roche) with protease inhibitor cocktail (PIC, Complete-M, Roche). The protein concentration was determined in samples (BCA protein assay, Pierce), which were mixed with Laemmli buffer and subjected to SDS-PAGE and western blotting [19]. For immunodetection, following antibodies were used: anti-cleaved PARP (CS9546), anti-cleaved lamin A (CS2036), anti-cleaved caspase-3 (CS9661), antiBid (CS2002) (Cell Signaling Technology), anti-DR4 (D3813), anti-DR5 (D3938), anti-Mcl-1 (M8434) (Sigma), anti-caspase-10 (M059-3, MBL), anti-FLIP (NF6, 804428, Axorra), anti-caspase-2 (BD611022), anti-FADD (BD556402), anti-cytochrome $c$ (BD556433), and antiBax (BD556467) (Becton Dickinson), anti-survivin (ab469, Abcam), anti-caspase-8 (provided by Prof. P. Krammer), anti-Bcl-2 (sc492), anti-Bcl- $\mathrm{X}_{\mathrm{L}}$ (sc-634) (Santa Cruz Biotechnology). The recognized proteins were detected using horseradish peroxidase-labelled secondary antibodies: anti-mouse IgG (31430, Pierce), anti-rabbit IgG (31460, Pierce), and enhanced chemiluminescence kit (Western blot detection reagent, GE Healthcare UK Limited). An equal loading was verified using anti- $\beta$-actin (A2066, Sigma), anti-G3PDH (2275, Trevingen) or anti-TOM40 (sc-11414, Santa Cruz Biotechnology, for mitochondrial fraction) antibodies. For detection of cytosolic and mitochondrial cytochrome $c$ and Bax, the cells were washed twice with PBS, incubated $\left(5 \mathrm{~min}, 4^{\circ} \mathrm{C}\right)$ in buffer $(250 \mathrm{mM}$ sucrose, $70 \mathrm{mM}$ $\mathrm{KCl}, 100 \mu \mathrm{g} / \mathrm{ml}$ digitonin in $\mathrm{PBS}$ ), centrifuged (5 min, $7000 \mathrm{~g}$ ), and the supernatant was collected (cytosolic fraction). Mitochondrial fraction was prepared by lysis of the pellet in Complete Lysis-M buffer with PIC (Roche).

\section{cFLIP and caspase-8 overexpression}

Twenty four hours after seeding, cells were transfected with DNA:Lipofectamine 2000 (Invitrogen) mixture at ratio $2 \mu \mathrm{g}: 1 \mu \mathrm{l}$ according to manufacturer's instructions. Following next $24 \mathrm{~h}$, medium was exchanged and the cells were treated $(8$ or $24 \mathrm{~h})$ with TRAIL $(100 \mathrm{ng} / \mathrm{ml})$, doxorubicin $(1 \mu \mathrm{M})$ or their combination. The following plasmids were used: pcDNA3 (Invitrogen), pcDNA3-Flag-

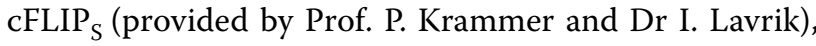

pcDNA-MACH alpha1 (provided by Prof. D. Wallach),

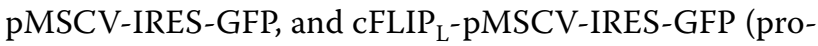
vided by Dr A. Grandien).

\section{cFLIP and caspase-8 siRNA experiments}

Three different specific siRNAs were used to downregulate (a) both long and short cFLIP, (b) the long form, or (c) the short form only. The non-targeting siRNA was used as control. All the siRNAs were synthesized by Qiagen according to Galligan et al. [20]. The siRNA was diluted in $100 \mu \mathrm{l}$ of Opti-MEM I medium (Gibco), and $1 \mu \mathrm{l}$ of Lipofectamine 2000 reagent (Invitrogen) was added to other $100 \mu \mathrm{l}$ of OptiMEM I medium. Diluted siRNA and Lipofectamine 2000 were then mixed and incubated for $20 \mathrm{~min}$. Transfection complexes were added $(200 \mu \mathrm{l}$ per well) to cells $24 \mathrm{~h}$ after seeding in 12 well plates. The final concentration of siRNA was $100 \mathrm{nM}$. After $24 \mathrm{~h}$, the medium was exchanged, and cells were treated $(24 \mathrm{~h})$ with TRAIL (100 ng/ml). For caspase-8 siRNA transfection, the same experimental protocol was used, and the cells were treated with TRAIL and/or doxorubicin $48 \mathrm{~h}$ after transfection. Caspase-8 siRNA (L-003466-00) and control siRNA (D-001810-10) were obtained from Dharmacon.

\section{MTS assay}

Cells were seeded in 96-well plates at a density of $10^{4}$ cells per well and $24 \mathrm{~h}$ later treated with various concentrations of the drugs. After next $24 \mathrm{~h}$, CellTiter 96 AQueous MTS Reagent Solution (Promega) was added to each well according to the manufacturer's instructions, and in $1 \mathrm{~h}$ the cell viability was determined by measuring the absorbance at $490 \mathrm{~nm}$ using Labsystems Multiscan MCC/340 plate reader.

\section{Analysis of nuclear morphology}

Cells were washed in PBS, fixed in ethanol (70\%), stained (30 $\mathrm{min})$ with 4,6-diamidino-2-phenyl-indole (DAPI, Fluka, $1 \mu \mathrm{g}$ DAPI/ml ethanol) and mounted in Mowiol. The percentage of apoptotic cells (with chromatin condensation and fragmentation) was calculated from a total number of 200 cells using LSM 510 META spectral laser scanner microscope (Zeiss).

\section{Analysis of DNA content}

For DNA analysis, cells were fixed in $70 \%$ cold ethanol overnight, washed, incubated $1 \mathrm{~h}$ at $37^{\circ} \mathrm{C}$ with RNAse A $(100 \mu \mathrm{g} / \mathrm{ml})$, and exposed to PI $(50 \mu \mathrm{g} / \mathrm{ml})$ in phosphatebuffered saline ( $\mathrm{pH}$ 7.4) for $30 \mathrm{~min}$. The cells were analyzed by flow cytometry (FACScan, Becton Dickinson) and CellQuest software. The cell death was monitored by evaluation of percentage of cells with subdiploid amount of DNA. 


\section{Statistical evaluation}

The results of three independent experiments were expressed as the means \pm S.E.M. Statistical significance ( $p$ $<0.05$ ) was determined by one-way ANOVA followed by Tukey test or by non-parametric Mann-Whitney test.

\section{Results \\ SCLC cell lines are resistant to TRAIL-induced apoptosis, and differ in the expression of proteins involved in TRAIL signaling}

All five SCLC cell lines studied - H69, H82, U1285, U1690, U1906 - were resistant to apoptotic effects of TRAIL (100 ng/ml), as demonstrated by the absence of PARP cleavage (Figure 1A) or caspase-3 processing (not shown) after $72 \mathrm{~h}$ of treatment. Expression of selected proteins important in TRAIL signaling was analyzed in untreated cell lines. We showed that only 1 (U1906) out of 5 cell lines expressed DR 4 at the surface, and 4 out of 5 cell lines (except for H69) did express DR5. While no surface DcR1 was present in any of cell lines, DcR2 was always detected (flow cytometry, Figure 1B). Despite its absence at the cell surface, all cell lines expressed (at various amounts) DR4 protein. The significant differences at the level of total DR5 protein were apparent among cell lines, being highest in U1906, not detectable in H69, and low in U1690 cells, which correlated with the cell surface levels. In spite of the relatively high amount of total DR5, its lower level was detected at the surface of U1285 cells (Figure 1C). While pro-caspase-8 was present in U1285 and U1690 cells, it was not detected in H82, H69, and U1906 cells. All cell lines expressed a relatively high level of pro-caspase-2, most abundantly in U1285 and U1690 cells. No pro-caspase-10 was detected in any of them (Figure 2A). All five cell lines expressed FADD protein (especially U1690). A relatively high level of long and short cFLIP form was apparent in H69, U1690, and U1906 cells. Both cFLIP forms were absent in H82 cells. In U1285 cells, only a low level of $\mathrm{cFLIP}_{\mathrm{L}}$ was detected (Figure 2B). The survivin expression differed significantly among the cell lines, being the highest in H82, U1285, and U1906. A relatively high level of Mcl-1 was found in the SCLC cells studied (except for H69 cells). Bcl-2 protein was detected in 2 out of the 5 cell lines (Figure 2C).

\section{Doxorubicin and etoposide sensitize SCLC cells expressing caspase-8 protein to TRAIL-induced apoptosis}

Based on the results presented in Figures 1 and 2, two cell lines - U1690 and U1285 - were selected for further investigations. Both expressed pro-caspase- 8 protein, an essential molecule for TRAIL apoptotic signaling, and a similar level of cell surface DR5. While we showed a strong induction of apoptosis (caspase-8, -3, and PARP cleavage) in U1690 and U1285 cells treated (24 h) with 1 $\mu \mathrm{M}$ PKC412 (positive control), the cells did not respond even to a relative high dose of TRAIL $(1 \mu \mathrm{g} / \mathrm{ml})$ (Figure 3A). In order to be sensitized to TRAIL-induced apoptosis, cells were co-treated with doxorubicin or etoposide. To determine a suitable concentration of chemotherapeutic drug, the dose response to this agent was investigated using MTS cytotoxicity test (data not shown). Two to three concentrations of the drugs (with low or no cytotoxicity) were then selected to be combined with TRAIL (100 ng/ml). When U1285 cells were simultaneously treated $(24 \mathrm{~h})$ with TRAIL and doxorubicin $(1$ or $2 \mu \mathrm{M})$, a dose-dependent potentiation of apoptosis (enhanced PARP and caspase-3 cleavage) was achieved compared to agents used alone (Figure $3 \mathrm{~B}$ and not shown). Similarly, a strong PARP cleavage was detected upon co-treatment of U1690 cells with TRAIL and doxorubicin $(0.5$ or $1 \mu \mathrm{M})$ as well as TRAIL and etoposide $(2.5$ or $5 \mu \mathrm{M})$ (Figure $3 \mathrm{~B}, \mathrm{C}$ ). To investigate the mechanisms involved in sensitization of SCLC cells expressing caspase-8 to apoptosis induced by combined treatment with TRAIL and chemotherapeutic drugs, treatment with doxorubicin was chosen and U1690 cells were subjected to more detailed study. A particular attention was paid to the involvement of caspases, mitochondria, and several important molecules of TRAIL signaling pathway. A substantial cleavage of procaspase- 8 and PARP was detected in cells co-treated (24 h) with doxorubicin $(1 \mu \mathrm{M})$ and different doses of TRAIL $(10-250 \mathrm{ng} / \mathrm{ml})$ (Figure 3D), together with increase in caspase-2, -3 activity (Figure $3 \mathrm{E}$ ) and processing (not shown). No changes of caspase-2, -3 activity (compared to control) were detected in cells treated with TRAIL, and a slight enhancement was observed after doxorubicin administration (Figure 3E). Pretreatment with z-VADfmk prevented the cooperative apoptotic effect of TRAIL and doxorubicin as demonstrated by inhibition of characteristic apoptotic changes in the nucleus (Figure 4A), and blockage of PARP and lamin A cleavage (Figure 4B). In the presence of z-VAD-fmk, TRAIL- and doxorubicininduced processing of caspase- 2 and -3 was completely blocked. However, the decrease of pro-caspase- 8 level, and generation of its $41 / 43$, but not $18 \mathrm{kDa}$ fragments were still detected (Figure 4B).

The combination of TRAIL and doxorubicin induced a significant decrease of full length Bid protein level, accompanied by increased amount of its cleavage product tBid (Figure 4C), a slight decrease of Bcl- $\mathrm{X}_{\mathrm{L}}$, but no significant changes of $\mathrm{Bcl}-2$ or $\mathrm{Mcl}-1$ protein levels compared to agents used alone (Figure 4C). Significant decrease of the survivin level was also detected in response to doxorubicin alone or its combination with TRAIL (Figure 4C). During $24 \mathrm{~h}$ treatment with TRAIL and doxorubicin, an increased translocation of Bax to mitochondria was observed (Figure 4C and not shown), which was associated with an increased percentage of cells with active Bax compared to TRAIL-treated (no Bax activation) or doxo- 
A

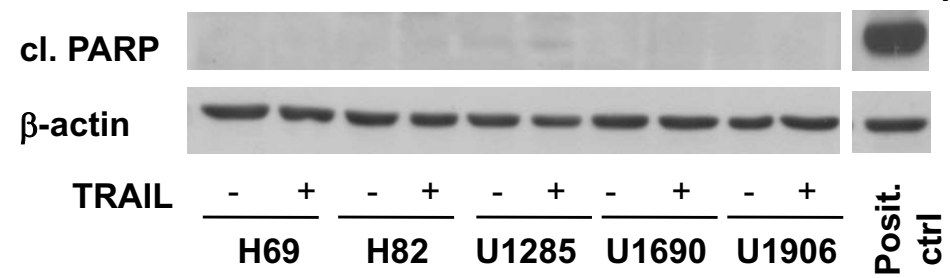

$\mathrm{kDa}$
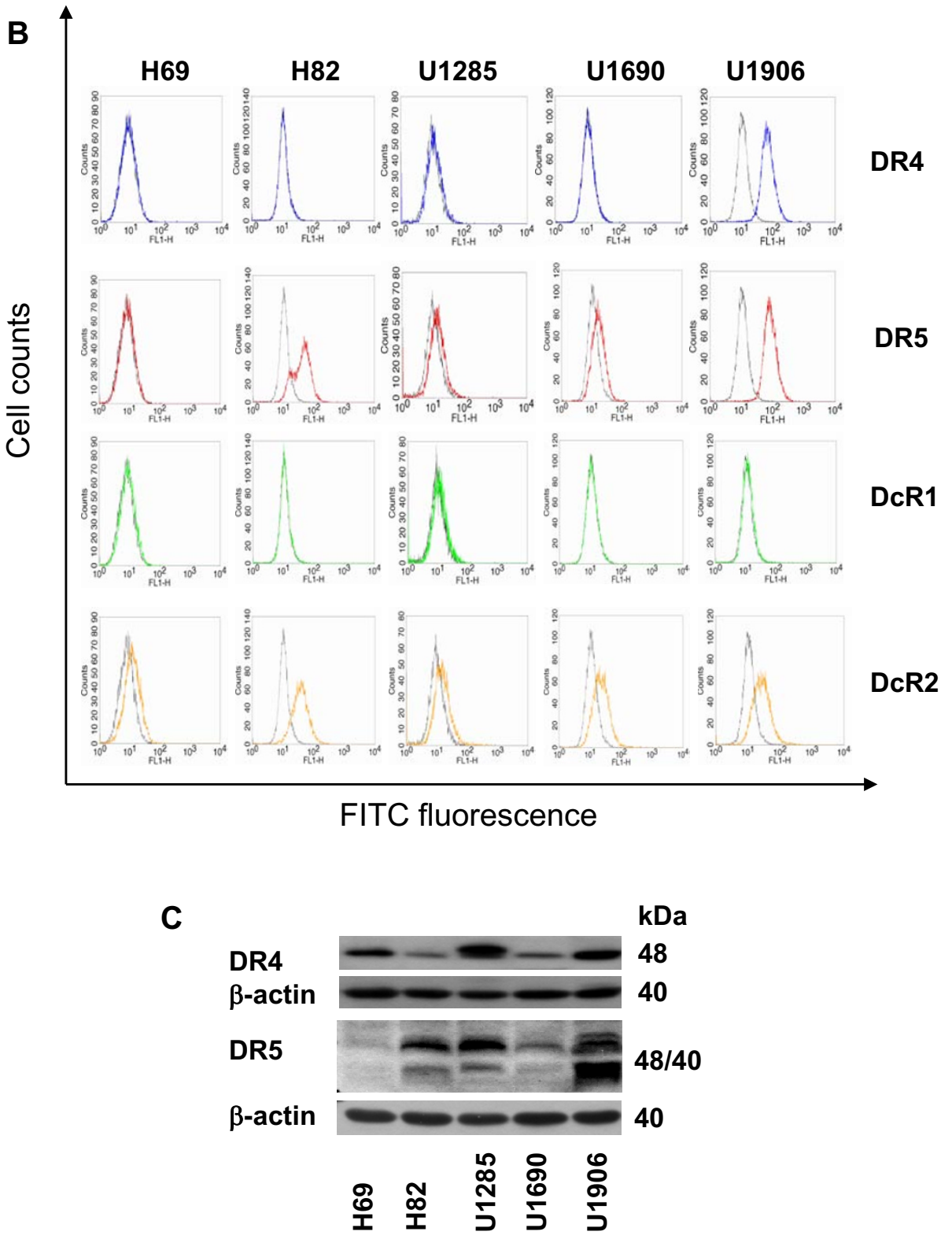

Figure 1 SCLC cell lines are resistant to TRAIL treatment and differ in expression of TRAIL receptors. (A) Cleavage of PARP was analyzed in H69, H82, U1285, U1690, and U1906 cells treated (72 h) with TRAIL (100 ng/ml). An equal loading was verified using anti- $\beta$-actin antibody. (B) Surface expression of DR4, DR5, DCR1, and DCR2 in these cells (flow cytometry, for details see Materials and methods, black lines - controls lacking primary antibody). (C) Total level of DR4 and DR5 in these cells. An equal loading was verified using anti- $\beta$-actin antibody. All results are representative of three independent experiments. 


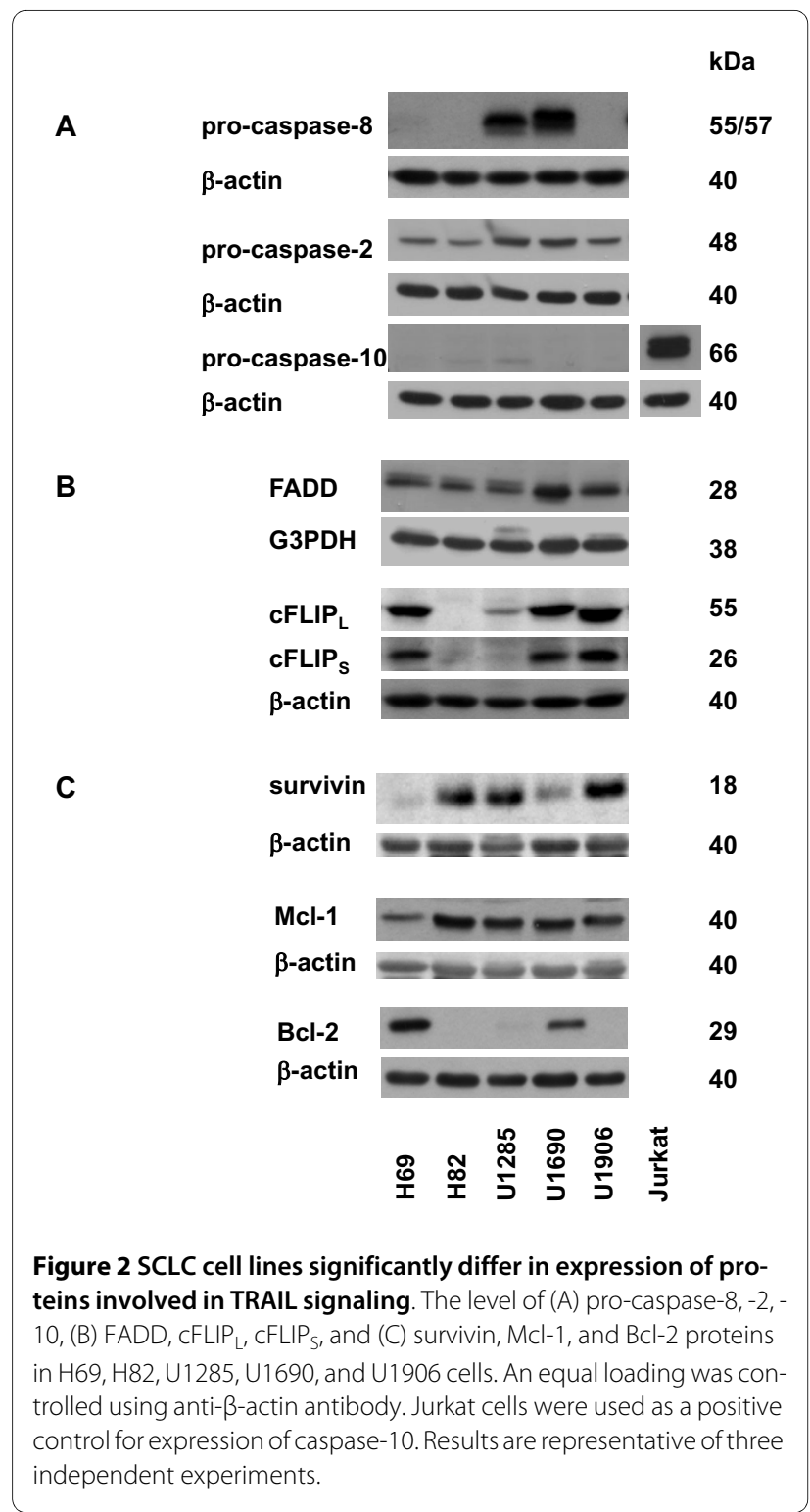

rubicin-treated (only low Bax activation) cells (Table 1). The redistribution of cytochrome $c$ from mitochondria to cytosol was demonstrated after $12 \mathrm{~h}$ (and especially after 16,20 , and $24 \mathrm{~h}$ ) of incubation with TRAIL and doxorubicin (Figure 4D). Treatment of U1690 cells with TRAIL and doxorubicin also induced significant increase in number of cells with decreased MMP, and with subdiploid DNA content (Table 1). To explore whether combination of doxorubicin or etoposide with TRAIL also exerted a cytotoxic effect in cells lacking caspase-8, the number of U1906 cells with subdiploid amount of DNA and decreased MMP was analyzed following the above mentioned treatments (Figure 4E). As expected, both drugs did not sensitize U1906 cells to TRAIL, demonstrating the requirement of caspase- 8 for sensitization of SCLC cells to TRAIL.

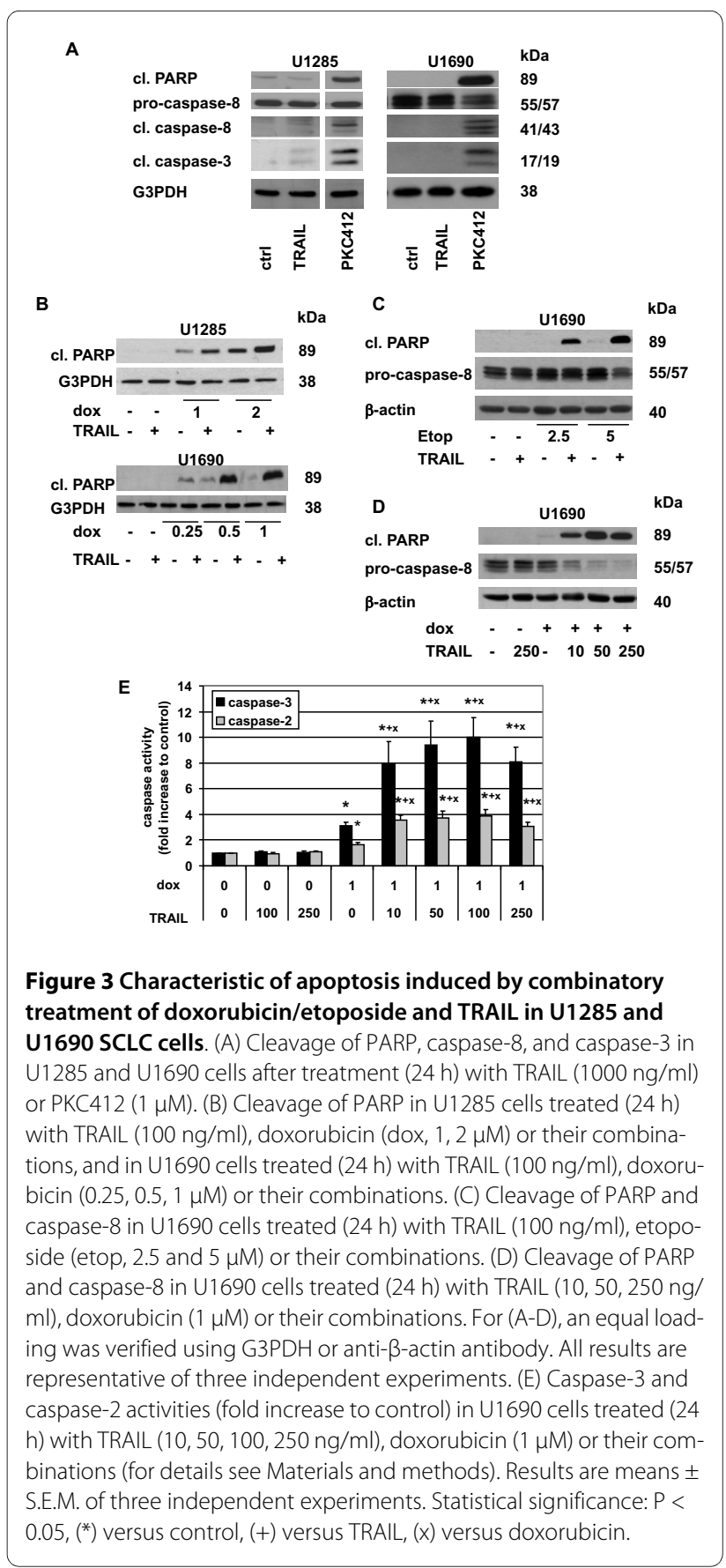

During the course of $24 \mathrm{~h}$ incubation of U1690 cells with TRAIL and doxorubicin, the changes of the expression or cleavage of several important proteins involved in TRAIL signaling were examined. A decrease of pro-caspase- 8 level, and accumulation of its $41 / 43$ and $18 \mathrm{kDa}$ fragments were apparent after $8 \mathrm{~h}$, and particularly after $12 \mathrm{~h}$ (Figure 5A), accompanied by a significant increase of caspase- 8 activity (data not shown) in TRAIL and doxorubicin-treated cells compared to the individual agents. Twenty-four hours of cell incubation with TRAIL and 


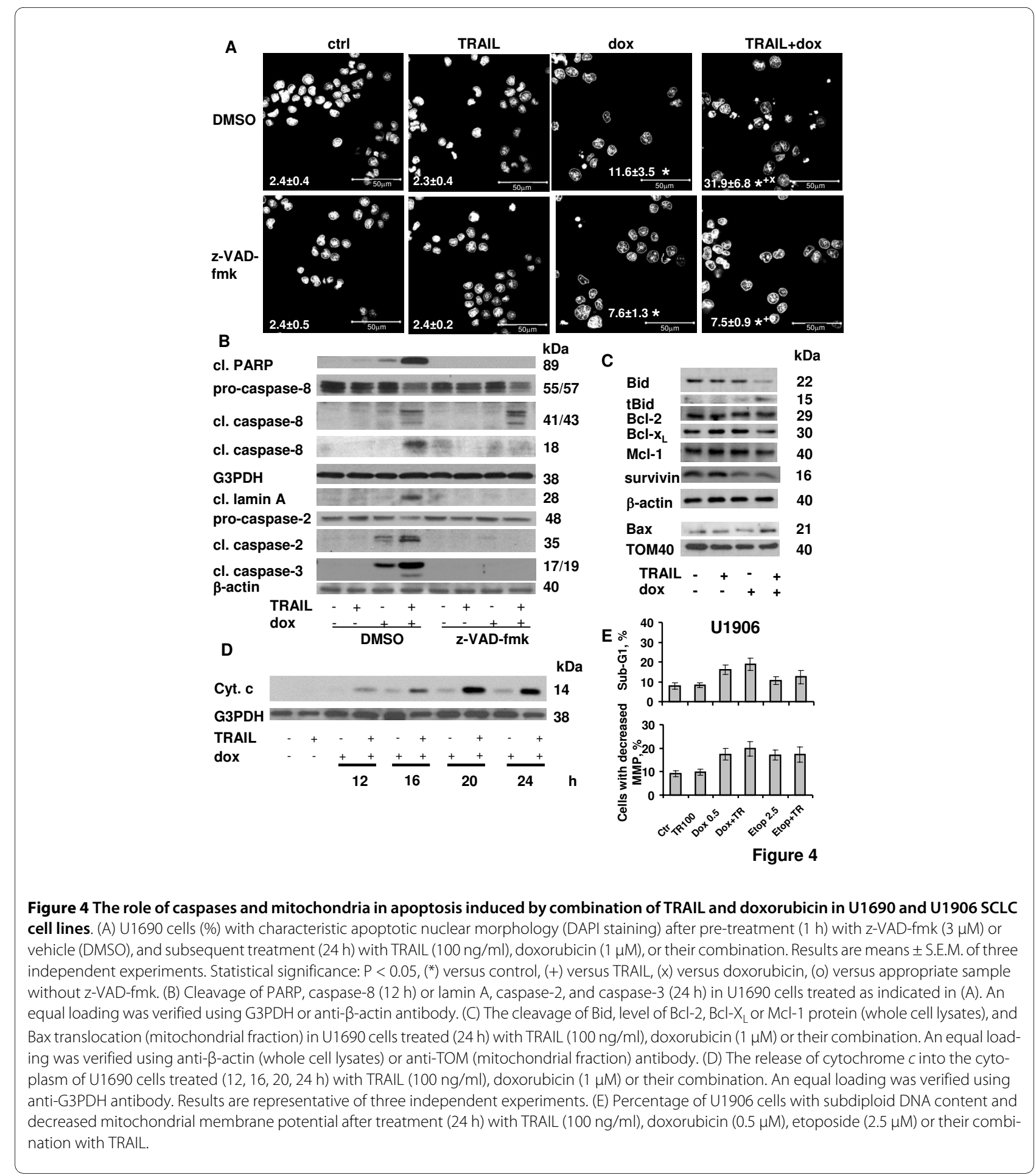

doxorubicin resulted in a complete loss of pro-caspase-8, and disappearance of its specific cleavage fragments due to their rapid degradation. A cleavage of $\operatorname{cFLIP}_{\mathrm{L}}$ to its 43 $\mathrm{kDa}$ fragment was detected during 8-24 $\mathrm{h}$ of combined treatment, and 12-24 h of doxorubicin administration. A decrease of $\mathrm{CFLIP}_{\mathrm{S}}$ after $12 \mathrm{~h}$, and its almost complete loss after $24 \mathrm{~h}$ of incubation with TRAIL and doxorubicin or doxorubicin alone was observed. During the first $12 \mathrm{~h}$, no changes of FADD level were detected after any type of treatment, but $24 \mathrm{~h}$ incubation of cells with TRAIL and doxorubicin resulted in significant decrease of FADD. Doxorubicin was responsible for significant up-regula- 
Table 1: Percentage of U1690 cells with decreased mitochondrial membrane potential, active Bax and subdiploid DNA content.

\begin{tabular}{|c|c|c|c|c|}
\hline$\%$ of cells & Control & TRAIL & Doxorubicin & TRAIL+Doxorubicin \\
\hline Decreased MMP & $2.3 \pm 0.6$ & $2.2 \pm 0.7$ & $13.4 \pm 1.8 *$ & $29.8 \pm 6.3^{*}+x$ \\
\hline Active Bax & $1.5 \pm 0.9$ & $2.8 \pm 0.4$ & $11.9 \pm 3.5^{*}$ & $44.1 \pm 5.3^{*+x}$ \\
\hline Sub-G1 & $4.9 \pm 0.6$ & $5.2 \pm 0.5$ & $21.9 \pm 3.4^{+*}$ & $40.4 \pm 1.7^{*+x}$ \\
\hline
\end{tabular}

tion of the total level of two DR5 protein forms, starting from $8 \mathrm{~h}$ in both doxorubicin- or TRAIL and doxorubicin-treated cells (Figure 5A). A significant doxorubicininduced increase of the surface DR5, but not DR4 was also found using flow cytometry (Figure $5 \mathrm{~B}$ and not shown). In order to demonstrate a key role of caspase-8, cells were transfected with control or caspase-8 siRNA and then treated (11 or $16 \mathrm{~h}$ ) with TRAIL and/or doxorubicin. Downregulation of caspase- 8 resulted in significant reduction of apoptosis, decreased PARP cleavage and caspase-2, -3 processing in TRAIL and doxorubicintreated cells (Figure 5C). Markedly, restoration of caspase-8 expression after caspase-8 siRNA-mediated silencing re-sensitized U1690 cells to undergo apoptosis induced by combination of doxorubicin with TRAIL (Figure

Several approaches were used to study the role of cFLIP in regulation of TRAIL-induced apoptosis. First, the cells were transfected with siRNA targeting $\mathrm{CFLIP}_{\mathrm{L}}$ and/or cFLIP. $_{S}$. Simultaneous elimination of the two cFLIP forms sensitized cells to apoptosis induced by TRAIL (100 ng/ $\mathrm{ml}, 24 \mathrm{~h}$ ), as demonstrated by enhanced cleavage of PARP, caspase-3, and increase of number of cells with apoptotic nuclear morphology, compared to control siRNA-transfected cells (Figure 6A). To be able to distinguish between the role of $\mathrm{CFLIP}_{\mathrm{L}}$ and $\mathrm{cFLIP}_{S}$, another set of experiments was carried out using two siRNAs selectively targetting either $\mathrm{CFLIP}_{\mathrm{L}}$, or $\mathrm{cFLIP}_{\mathrm{S}}$. In this case, more intensive TRAIL-induced apoptotic response (increased PARP cleavage) was apparent in cells transfected with cFLIP $_{\mathrm{L}}$ siRNA (Figure 6B). Second, CHX was used to eliminate cFLIP $_{\mathrm{L} / \mathrm{S}}$ in U1690 cells, which was associated with their sensitization to TRAIL-induced apoptosis shown by enhanced cleavage of PARP and caspase-8 (Figure 6C). Third, the response to TRAIL and doxorubicin was examined following cell transfection with $\mathrm{CFLIP}_{\mathrm{L}}$ or cFLIP $_{S}$ vectors. Overexpression of $\mathrm{cFLIP}_{\mathrm{L}}$ or $\mathrm{cFLIP}_{\mathrm{S}}$ rendered cells less sensitive to apoptosis induced by combination of TRAIL and doxorubicin (Figure 6D).

\section{Discussion}

SCLC is a tumour entity where TRAIL monotherapy is not efficient. The loss of some DISC components, associated with inactivation of DR pathway make sensitization of the SCLC cells to TRAIL very difficult $[9,10,12,21]$. Caspase- 8 is frequently silenced in SCLC and other tumours of neuroendocrine origin, usually by aberrant promoter methylation $[22,23]$. According to our results, 3 out of 5 studied SCLC cell lines were deficient for caspase-8, all lacked caspase-10, and only 1 cell line expressed surface DR4. Previously, restoration of caspase- 8 expression by demethylation or gene transfer was shown to sensitize neuroblastoma cells to DR-mediated apoptosis [23]. It has also been suggested that the resistance of SCLC cells lacking caspase- 8 to TRAIL might be partially eliminated by combination of demethylation agents and treatment with IFNY [10]. However additional studies should be performed in order to elucidate how general this phenomenon is.

Notably, we and others found that caspase- 8 expressing SCLC cells are also resistant to TRAIL-induced apoptosis. Therefore, we aimed to investigate whether the cytotoxic effects of TRAIL in SCLC could be restored by doxorubicin or etoposide, the conventionally used drugs for treatment of SCLC, and what are the mechanisms responsible for apoptosis resistance of caspase-8 expressing SCLC cells. Our results demonstrated that combination of these drugs with TRAIL might significantly improve efficiency to kill this type of SCLC cells as compared with drugs used alone.

The presence of TRAIL death receptors DR4 and/or DR5 at the cell surface is not always sufficient to trigger apoptosis and that might be due to an existence of the defects of intracellular signaling pathways or high expression of inhibitory proteins. Upregulation of DRs following treatment with chemotherapeutic agents has been demonstrated in some cancer cells, while no effects were apparent in others $[24,25]$. This upregulation has been shown to be responsible for the synergistic action of TRAIL and chemotherapy in several cell lines [26-28]. In 
A
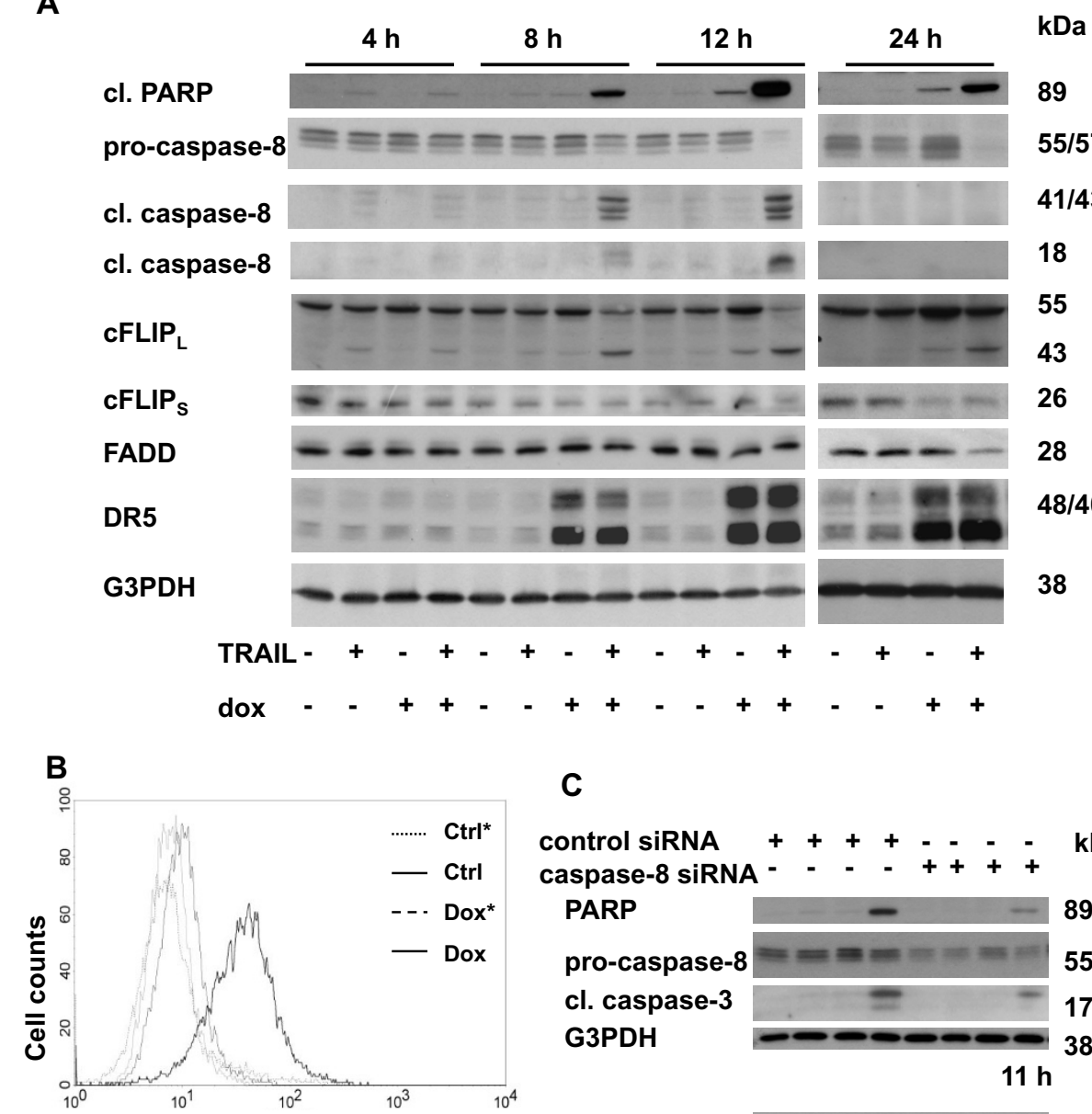

C

AlexaFluor-488 fluorescence

D

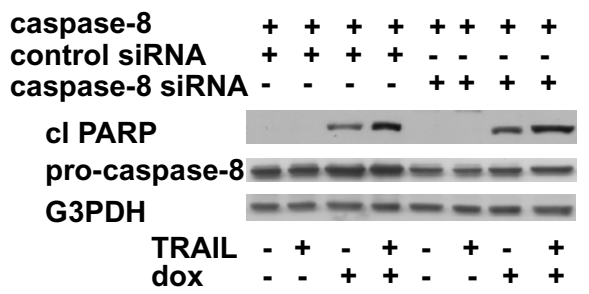

control siRNA $++++---; \mathrm{kDa}$ caspase-8 siRNA - - - ++++

$\begin{array}{lll}\text { PARP } & - & -19\end{array}$

pro-caspase-8 $=-=-2=-55 / 57$

cl. caspase-3 = $=17 / 19$

G3PDH

$11 \mathrm{~h}$

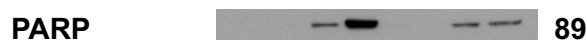

pro-caspase- $8===\quad===\quad 55 / 57$

cl. caspase-3 $3=17 / 19$

pro-caspase-2

cl. caspase-2 $---=-\cdots \div * 35$

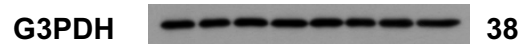

$16 \mathrm{~h}$

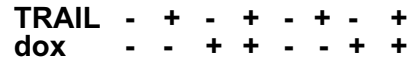

Figure 5 Time-dependent changes in the expression level of apical proteins involved in TRAIL signaling pathway and an esesential role of caspase-8 in apoptosis induced by combined treatment of doxorubicin and TRAIL in U1690 cells. (A) Cleavage of PARP, caspase-8, CFLIP, and the level of cFLIP, $F A D D$, and DR5 in U1690 cells treated $(4,8,12,24 \mathrm{~h})$ with TRAIL $(100 \mathrm{ng} / \mathrm{ml})$, doxorubicin $(1 \mu \mathrm{M})$ or their combination. An equal loading was controlled using anti-G3PDH antibody. (B) The surface level of DR5 in U1690 cells untreated or treated (24 h) with doxorubicin (1 $\mu \mathrm{M})$, detected by flow cytometry, using specific primary mouse anti-DR5 antibody, followed by anti-mouse secondary AlexaFluor-488-conjugated antibody. Cells incubated with secondary antibody alone (marked by asterisk) were used to check the background fluorescence. Results are representative of three independent experiments. (C) Cleavage of PARP or caspase-8,-3,-2 in U1690 cells transfected (48 h) with control or caspase-8 siRNA, and then treated $(11$ or $16 \mathrm{~h}$ ) with TRAIL $(100 \mathrm{ng} / \mathrm{ml})$, doxorubicin $(1 \mu \mathrm{M})$ or their combination. An equal loading was verified using anti-G3PDH antibody. An asterisk indicated unspecific antibody staining. (D) Cleavage of PARP and level of caspase-8 in U1690 cells transfected (48 h) with control or caspase8 siRNA, then transfected with pcDNA-MACH alpha 1 (caspase-8) expressing vector (200 ng) and treated (16 h) with TRAll (100 ng/ml), doxorubicin $(1 \mu \mathrm{M})$ or their combination. An equal loading was verified using anti-G3PDH antibody. 
A
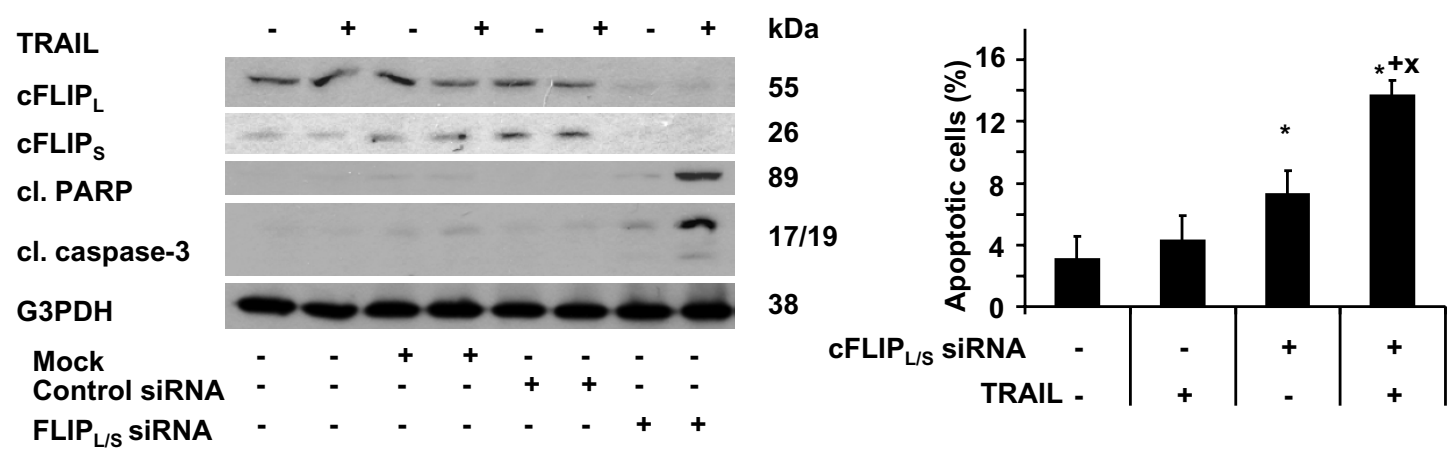

B

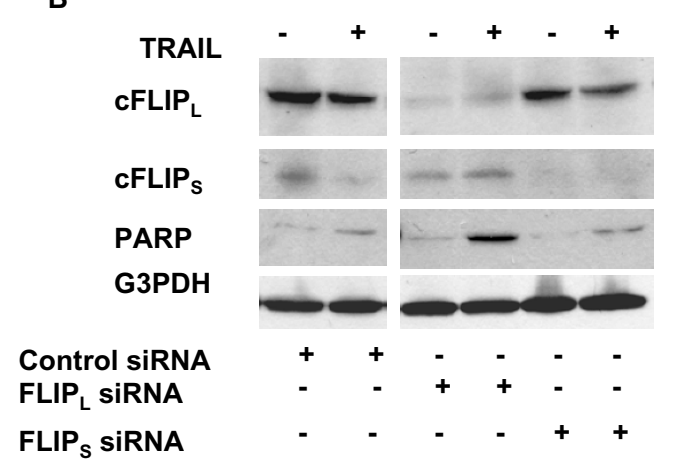

C

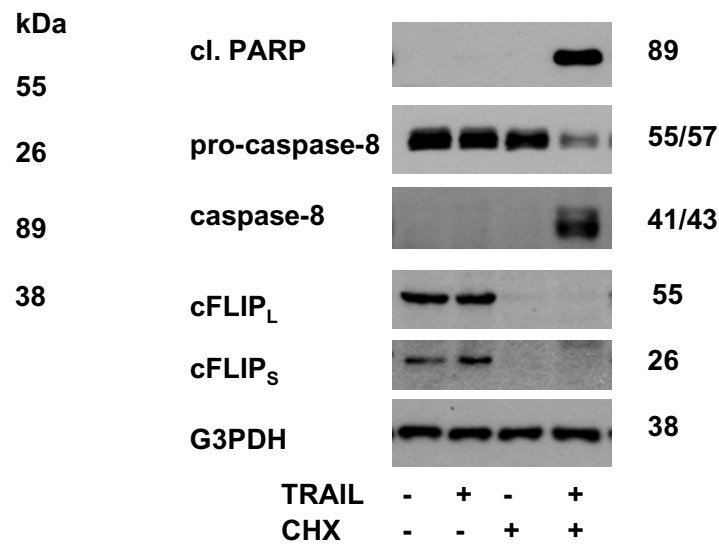

D
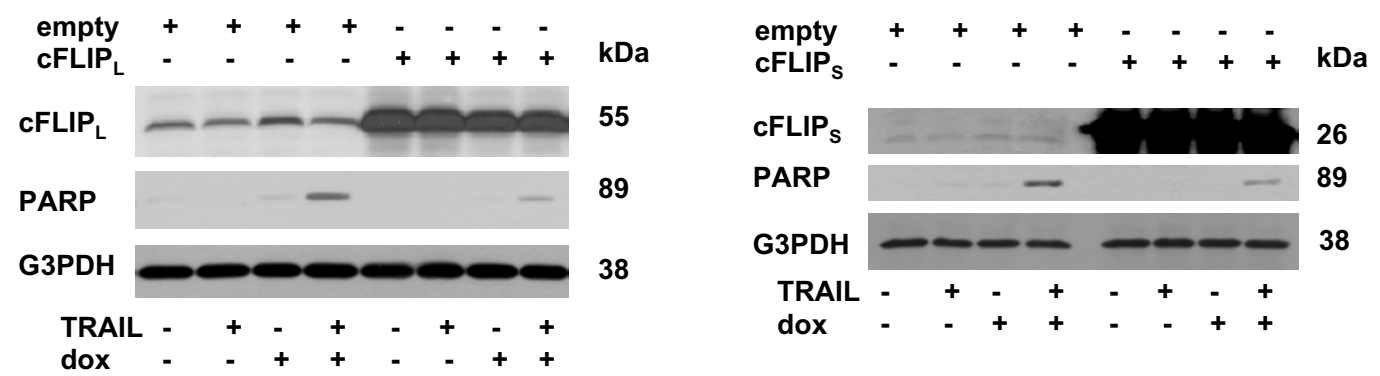

Figure 6 The role of cFLIP in response of U1690 cells to combined treatment of TRAIL and doxorubicin. (A) Cleavage of PARP and caspase-3 in U1690 cells non-transfected, mock-transfected (Lipofectamine 2000 only) or transfected ( 24 h) with FLIP L/S or control siRNA, and then treated (24 h) with TRAIL (100 ng/ml). Percentage of cells with apoptotic nuclear morphology after transfection (24 h) with FLIP L/S Or control siRNAs and subsequent treatment $(24 \mathrm{~h})$ with TRAIL $(100 \mathrm{ng} / \mathrm{ml})$. Results are means \pm S.E.M. of three independent experiments. Statistical significance: $P<0.05$, $\left({ }^{*}\right)$ versus control, $(+)$ versus TRAIL, $(x)$ versus doxorubicin. (B) Cleavage of PARP in U1690 cells transfected $(24 \mathrm{~h})$ with $C F L I P_{L^{\prime}}, C F L I P_{S}$ or control siRNA, and then treated

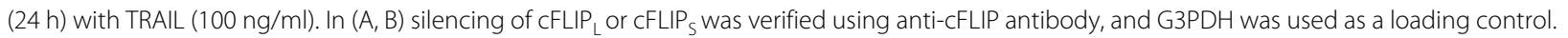
(C) Cleavage of PARP, caspase-8, and CFLIP or CFLIP level in U1690 cells pre-treated (1 h) with CHX (5 Mg/ml), and then treated (12 h) with TRAIL (100 $\mathrm{ng} / \mathrm{ml}$ ). An equal loading was verified using anti-G3PDH antibody. (D) Cleavage of PARP in U1690 cells transfected (24 h) with CFLIP $\mathrm{L}^{\prime}, \mathrm{CFLIP} \mathrm{P}_{\mathrm{S}}$ or empty vectors, and then treated ( 24 or $8 \mathrm{~h}$, respectively) with TRAIL $(100 \mathrm{ng} / \mathrm{ml})$. Overexpression of FLIP $\mathrm{O}_{\mathrm{L}} \mathrm{CFLIP}_{\mathrm{S}}$ was controlled using anti-cFLIP antibody, and G3PDH was used as a loading control. Results are representative of three independent experiments. 
our experiments, untreated U1690 cells expressed a relatively low level of DR5 and no DR4 at the surface. Significant increase of surface DR5, but not DR4 was observed after treatment with doxorubicin, and no significant changes of DcRs level (not shown) as has been demonstrated by others [29]. Our results, therefore, suggest that DR5 plays an exclusive role in mediation of signals triggered by TRAIL in these cells. Furthermore, relocalisation and clustering of DR5 within ceramide-enriched membrane platforms has been reported to affect TRAILinduced apoptosis in cells treated with doxorubicin [30]. Similar changes at the level of plasma membrane might be also involved in enhancement of TRAIL apoptotic signaling in SCLC cells.

Caspase- 8 activation at the DISC proceeds through two subsequent cleavage steps that can be effectively regulated by cFLIP proteins. While cFLIP $_{\mathrm{L}}$ allows the first cleavage of pro-caspase-8, cFLIP $_{S}$ can completely inhibit both of them [31]. cFLIP is known to play an important role in regulation of TRAIL- and chemotherapy-induced apoptosis [20,32,33]. Doxorubicin-induced downregulation of cFLIP $_{S}$ contributed to sensitization of prostate cancer cells to apoptotic effects of TRAIL [34,35]. Significant decrease of $\mathrm{CFLIP}_{\mathrm{L} / \mathrm{S}}$ level and appearance of specific p43-cFLIP ${ }_{\mathrm{L}}$ fragment following doxorubicin or TRAIL and doxorubicin treatment indicated their involvement in modulation of apoptotic response of U1690 cells to TRAIL. The role of $\mathrm{p} 43-$ cFLIP $_{\mathrm{L}}$ in regulation of caspase-8 activation is still controversial, as both anti- and proapoptotic functions of this fragment have been demonstrated [36,37]. CHX-mediated downregulation of cFLIP level previously published also in some other cancer cell types [38,39], resulted in sensitization of U1690 cells to TRAIL-induced apoptosis, showing that resistance of these cells may be at least partially induced by newly synthesized proteins acting upstream of caspase-8. The siRNA-mediated downregulation of $\mathrm{cFLIP}_{\mathrm{L} / \mathrm{S}}$ sensitized U1690 cells to TRAIL-induced apoptosis, although to a significantly lesser extent than combination of TRAIL with doxorubicin or etoposide. Moreover, overexpression of $\mathrm{CFLIP}_{\mathrm{L}}$ or $\mathrm{CFLIP}_{\mathrm{S}}$ only partially protected the cells from apoptosis induced by this combinatory treatment. Recently, it has also been shown that silencing of cFLIP induced caspase- 8 activation via increased co-localisation of DR5 and ceramide, and significantly enhanced TRAILinduced apoptosis [40]. Therefore, our results suggest that elimination of cFLIP itself as a single factor may not be sufficient to fully restore the sensitivity to TRAILinduced apoptosis, and modulation(s) at the level of other molecule(s) such as DR5 need to be involved.

Various chemotherapeutic drugs are known to trigger intrinsic apoptotic pathway [41] and/or increase a susceptibility of mitochondria to apoptotic signals translo- cated from DRs $[25,42,43]$. In our experiments we detected an increase of caspase-2 activity that was previously shown as a critical component of DNA damageinduced apoptotic cascade, being activated upstream of mitochondria [44]. Role of caspase-2 as initiator caspase was also observed in apoptosis triggered by other chemotherapeutic drugs $[14,45]$. In addition to acting as an initiator caspase primarily activated in DR-mediated apoptosis at the DISC level, caspase- 8 has also been reported to be activated by other caspases downstream of mitochondria during drug-induced apoptosis [46-48]. This led us to investigate the role of mitochondria and the ordering of caspase activation. Since z-VAD-fmk efficiently blocked TRAIL and doxorubicin-induced cleavage of caspase-2, -3, PARP, lamin A, apoptotic nuclear morphology changes, but not generation of caspase- 8 p41/43 $\mathrm{kDa}$ fragment, we suggested that the first caspase- 8 cleavage step might occur prior to and independently on the activation of other caspases. Moreover, our results demonstrated that siRNA-mediated downregulation of caspase- 8 resulted in marked decrease of TRAIL and doxorubicin-induced processing of caspase- 2 and -3 , and overall apoptosis, while re-expression of caspase- 8 fully reverted the apoptotic phenotype. Furthermore, a rapid processing of caspase- 8 was a relatively early event in the course of TRAIL and doxorubicin-induced apoptosis compared to attenuated kinetics of mitochondrial events, such as cytochrome $c$ release. Therefore, we assume that chemotherapy-mediated modulation of events leading to caspase- 8 activation following TRAIL treatment occurs upstream of mitochondria and effector caspases.

As TRAIL by itself did not induce caspase- 8 processing, it is likely that the resistance to TRAIL-induced apoptosis is regulated by protein(s) acting upstream of this molecule. Here we demonstrated that doxorubicin was efficient in sensitizing the cells to apoptotic effects of TRAIL that was associated with significant increase of surface and total DR5 level, activation of caspase cascade through processing of caspase-8, specific cleavage of $\mathrm{CFLIP}_{\mathrm{L}}$, and decrease of cFLIP $_{S}$. Cellular apoptosis was accompanied by cleavage of Bid, Bax activation, decrease of MMP, cytochrome $c$ release, decrease of survivin level, and effector caspase activation. Based on the caspase- 8 siRNA approach and experiments with z-VAD-fmk we concluded that combination of TRAIL and doxorubicin facilitates caspase- 8 processing primarily at the DISC level rather than being secondary result of activation of mitochondrial pathway and/or effector caspases. We suggest the possibility of sensitization of SCLC cells to TRAIL by modulation of the apical events in TRAIL apoptotic signaling at the level of surface DR5 and intracellular inhibitory molecules such as cFLIP.

In summary, although TRAIL monotherapy is completely inefficient in SCLC cells due to defects in initial 
steps of the DR-mediated pathway, combined treatment with TRAIL and conventional chemotherapeutic drugs, such as doxorubicin and etoposide, might be a promising therapeutic strategy for SCLC expressing caspase-8. Our results showed that doxorubicin and etoposide significantly sensitized these cells to TRAIL-induced apoptosis by modulation of events that facilitate activation of caspase-8. Our study highlights the potential applicability of this combination in chemotherapy of SCLC.

\section{Abbreviations}

BSA: bovine serum albumin; CHX: cycloheximide; DcR: decoy receptor; DISC death-inducing signaling complex; DR: death receptor; FADD: Fas-associated death domain; FBS: fetal bovine serum; FLIP: FLICE-like inhibitory protein; LC: lung cancer; NSCLC: non-small cell lung carcinoma; PARP: poly(ADP)ribose polymerase; SCLC: small cell lung carcinoma; TNF: tumour necrosis factor; TRAIL: TNF-related apoptosis-inducing ligand.

\section{Competing interests}

The authors declare that they have no competing interests.

\section{Authors' contributions}

AV and VK equally contributed to this work. They were involved in planning and performing experiments, carried out analysis of data and participated in writing of the MS. EJ and OS carried out experiments. BZ participated in the design of the experiments and writing the manuscript. All authors read and approved the final manuscript.

\section{Acknowledgements}

The authors thank Dr L. Andera for providing TRAIL, Prof. P. Krammer and Dr I. Lavrik for anti-caspase-8 antibody and pcDNA3-Flag-CFLIP, Prof. D. Wallach for pcDNA-MACH alpha1, and Dr A. Grandien for pMSCV-IRES-GFP and CFLIP $\mathrm{L}^{-}$ pMSCV-IRES-GFP vectors. This study was supported by grants from the Swedish and Stockholm Cancer Societies, the Swedish Research Council, the Swedish Childhood Cancer Foundation, the EC FP-6 (Oncodeath and Chemores) as well as the FP7 (Apo-Sys) programs. AV was supported by fellowship from the Wenner-Gren Foundation, VK and OS - by the Swedish Institute and Karolinska Institutet, and EJ - by the Iranian Government.

\section{Author Details}

Institute of Environmental Medicine, Division of Toxicology, Karolinska Institutet, Box 210, SE-171 77 Stockholm, Sweden

Received: 8 September 2009 Accepted: 23 April 2010

Published: 23 April 2010

\section{References}

1. Zhivotovsky B, Orrenius S: Defects in the apoptotic machinery of cancer cells: role in drug resistance. Semin Cancer Biol 2003, 13:125-134.

2. Rodriguez-Nieto S, Zhivotovsky B: Role of alterations in the apoptotic machinery in sensitivity of cancer cells to treatment. Curr Pharm Des 2006, 12:4411-4425

3. Wiley SR, Schooley K, Smolak PJ, Din WS, Huang CP, Nicholl JK, Sutherland GR, Smith TD, Rauch C, Smith CA, et al.: Identification and characterization of a new member of the TNF family that induces apoptosis. Immunity 1995, 3:673-682.

4. Newsom-Davis T, Prieske S, Walczak H: Is TRAIL the holy grail of cancer therapy? Apoptosis 2009, 14:607-623.

5. Koschny R, Walczak H, Ganten TM: The promise of TRAIL--potential and risks of a novel anticancer therapy. J Mol Med 2007, 85:923-935.

6. MacFarlane M: TRAIL-induced signalling and apoptosis. Toxicol Lett 2003, 139:89-97

7. Ashkenazi A, Pai RC, Fong S, Leung S, Lawrence DA, Marsters SA, Blackie C, Chang L, McMurtrey AE, Hebert A, et al:: Safety and antitumor activity of recombinant soluble Apo2 ligand. J Clin Invest 1999, 104:155-162.

8. Walczak H, Miller RE, Ariail K, Gliniak B, Griffith TS, Kubin M, Chin W, Jones J, Woodward A, Le T, et al:: Tumoricidal activity of tumor necrosis factorrelated apoptosis-inducing ligand in vivo. Nat Med 1999, 5:157-163.
9. Shivapurkar N, Reddy J, Matta H, Sathyanarayana UG, Huang CX, Toyooka S, Minna JD, Chaudhary PM, Gazdar AF: Loss of expression of deathinducing signaling complex (DISC) components in lung cancer cell lines and the influence of MYC amplification. Oncogene 2002, 21:8510-8514

10. Hopkins-Donaldson S, Ziegler A, Kurtz S, Bigosch C, Kandioler D, Ludwig C, Zangemeister-Wittke $U$, Stahel R: Silencing of death receptor and caspase- 8 expression in small cell lung carcinoma cell lines and tumors by DNA methylation. Cell Death Differ 2003, 10:356-364.

11. Shivapurkar N, Reddy J, Chaudhary PM, Gazdar AF: Apoptosis and lung cancer: a review. J Cell Biochem 2003, 88:885-898.

12. Joseph B, Ekedahl J, Sirzen F, Lewensohn R, Zhivotovsky B: Differences in expression of pro-caspases in small cell and non-small cell lung carcinoma. Biochem Biophys Res Commun 1999, 262:381-387.

13. Adams JM, Cory S: Bcl-2-regulated apoptosis: mechanism and therapeutic potential. Curr Opin Immunol 2007, 19:488-496.

14. Robertson JD, Enoksson M, Suomela M, Zhivotovsky B, Orrenius S: Caspase-2 acts upstream of mitochondria to promote cytochrome $c$ release during etoposide-induced apoptosis. J Bio/ Chem 2002, 277:29803-29809.

15. Wu XX, Ogawa O, Kakehi Y: TRAIL and chemotherapeutic drugs in cancer therapy. Vitam Horm 2004, 67:365-383.

16. Debatin KM, Krammer PH: Death receptors in chemotherapy and cancer. Oncogene 2004, 23:2950-2966.

17. Bergh J, Nilsson K, Ekman R, Giovanella B: Establishment and characterization of cell lines from human small cell and large cell carcinomas of the lung. Acta Pathol Microbiol Immunol Scand A 1985, 93:133-147

18. Walczak $H$, Haas TL: Biochemical analysis of the native TRAIL deathinducing signaling complex. Methods Mol Biol 2008, 414:221-239.

19. Vaculova A, Zhivotovsky B: Caspases: determination of their activities in apoptotic cells. Methods Enzymo/ 2008, 442:157-181

20. Galligan L, Longley DB, McEwan M, Wilson TR, McLaughlin K, Johnston PG: Chemotherapy and TRAIL-mediated colon cancer cell death: the roles of p53, TRAIL receptors, and c-FLIP. Mol Cancer Ther 2005, 4:2026-2036.

21. Belyanskaya LL, Ziogas A, Hopkins-Donaldson S, Kurtz S, Simon HU, Stahel $R$, Zangemeister-Wittke U: TRAIL-induced survival and proliferation of SCLC cells is mediated by ERK and dependent on TRAIL-R2/DR5 expression in the absence of caspase-8. Lung Cancer 2008, 60:355-365.

22. Shivapurkar N, Toyooka S, Eby MT, Huang CX, Sathyanarayana UG, Cunningham HT, Reddy JL, Brambilla E, Takahashi T, Minna JD, et al: Differential inactivation of caspase- 8 in lung cancers. Cancer Biol Ther 2002, 1:65-69.

23. Fulda S, Kufer MU, Meyer E, van Valen F, Dockhorn-Dworniczak B, Debatin KM: Sensitization for death receptor- or drug-induced apoptosis by reexpression of caspase- 8 through demethylation or gene transfer. Oncogene 2001, 20:5865-5877.

24. Lacour S, Hammann A, Wotawa A, Corcos L, Solary E, Dimanche-Boitrel MT: Anticancer agents sensitize tumor cells to tumor necrosis factorrelated apoptosis-inducing ligand-mediated caspase- 8 activation and apoptosis. Cancer Res 2001, 61:1645-1651.

25. Liu W, Bodle E, Chen JY, Gao M, Rosen GD, Broaddus VC: Tumor necrosis factor-related apoptosis-inducing ligand and chemotherapy cooperate to induce apoptosis in mesothelioma cell lines. Am J Respir Cell Mol Biol 2001, 25:111-118.

26. Wu XX, Jin XH, Zeng Y, El Hamed AM, Kakehi Y: Low concentrations of doxorubicin sensitizes human solid cancer cells to tumor necrosis factor-related apoptosis-inducing ligand (TRAIL)-receptor (R) 2mediated apoptosis by inducing TRAIL-R2 expression. Cancer Sci 2007, 98:1969-1976.

27. Nagane M, Pan G, Weddle JJ, Dixit VM, Cavenee WK, Huang HJ: Increased death receptor 5 expression by chemotherapeutic agents in human gliomas causes synergistic cytotoxicity with tumor necrosis factorrelated apoptosis-inducing ligand in vitro and in vivo. Cancer Res 2000, 60:847-853

28. MacFarlane M, Harper N, Snowden RT, Dyer MJ, Barnett GA, Pringle JH, Cohen GM: Mechanisms of resistance to TRAIL-induced apoptosis in primary B cell chronic lymphocytic leukaemia. Oncogene 2002, 21:6809-6818

29. Liu X, Yue P, Khuri FR, Sun SY: Decoy receptor 2 (DcR2) is a p53 target gene and regulates chemosensitivity. Cancer Res 2005, 65:9169-9175. 
30. Dumitru CA, Carpinteiro A, Trarbach T, Hengge UR, Gulbins E: Doxorubicin enhances TRAIL-induced cell death via ceramideenriched membrane platforms. Apoptosis 2007, 12:1533-1541.

31. Krueger A, Schmitz I, Baumann S, Krammer PH, Kirchhoff S: Cellular FLICEinhibitory protein splice variants inhibit different steps of caspase-8 activation at the CD95 death-inducing signaling complex. J Biol Chem 2001, 276:20633-20640.

32. Geserick P, Drewniok C, Hupe M, Haas TL, Diessenbacher P, Sprick MR, Schon MP, Henkler F, Gollnick H, Walczak H, Leverkus M: Suppression of CFLIP is sufficient to sensitize human melanoma cells to TRAIL- and CD95L-mediated apoptosis. Oncogene 2008, 27:3211-3220.

33. Leverkus M, Neumann M, Mengling T, Rauch CT, Brocker EB, Krammer PH, Walczak H: Regulation of tumor necrosis factor-related apoptosisinducing ligand sensitivity in primary and transformed human keratinocytes. Cancer Res 2000, 60:553-559.

34. Kelly MM, Hoel BD, Voelkel-Johnson C: Doxorubicin pretreatment sensitizes prostate cancer cell lines to TRAIL induced apoptosis which correlates with the loss of c-FLIP expression. Cancer Biol Ther 2002, 1:520-527.

35. White SJ, Lu P, Keller GM, Voelkel-Johnson C: Targeting the short form of CFLIP by RNA interference is sufficient to enhance TRAIL sensitivity in PC3 prostate carcinoma cells. Cancer Biol Ther 2006, 5:1618-1623.

36. Guseva NV, Rokhlin OW, Taghiyev AF, Cohen MB: Unique resistance of breast carcinoma cell line T47D to TRAIL but not anti-Fas is linked to p43cFLIP(L). Breast Cancer Res Treat 2008, 107:349-357.

37. Xiao C, Yang BF, Song JH, Schulman H, Li L, Hao C: Inhibition of CaMKIImediated c-FLIP expression sensitizes malignant melanoma cells to TRAIL-induced apoptosis. Exp Cell Res 2005, 304:244-255.

38. Kreuz S, Siegmund D, Scheurich P, Wajant H: NF-kappaB inducers upregulate CFLIP, a cycloheximide-sensitive inhibitor of death receptor signaling. Mol Cell Biol 2001, 21:3964-3973.

39. Wajant H, Haas E, Schwenzer R, Muhlenbeck F, Kreuz S, Schubert G, Grell $M$, Smith C, Scheurich P: Inhibition of death receptor-mediated gene induction by a cycloheximide-sensitive factor occurs at the level of or upstream of Fas-associated death domain protein (FADD). J Biol Chem 2000, 275:24357-24366

40. Wilson TR, Redmond KM, McLaughlin KM, Crawford N, Gately K, O'Byrne K, Le-Clorrenec C, Holohan C, Fennell DA, Johnston PG, Longley DB: Procaspase 8 overexpression in non-small-cell lung cancer promotes apoptosis induced by FLIP silencing. Cell Death Differ 2009, 16(10):1352-61

41. Panaretakis T, Pokrovskaja K, Shoshan MC, Grander D: Activation of Bak Bax, and $\mathrm{BH} 3-$ only proteins in the apoptotic response to doxorubicin. J Biol Chem 2002, 277:44317-44326.

42. Nguyen DM, Yeow WS, Ziauddin MF, Baras A, Tsai W, Reddy RM, Chua A, Cole GW Jr, Schrump DS: The essential role of the mitochondriadependent death-signaling cascade in chemotherapy-induced potentiation of Apo2L/TRAIL cytotoxicity in cultured thoracic cancer cells: amplified caspase 8 is indispensable for combination-mediated massive cell death. Cancer J 2006, 12:257-273.

43. Shamimi-Noori S, Yeow WS, Ziauddin MF, Xin H, Tran TL, Xie J, Loehfelm A, Patel P, Yang J, Schrump DS, et al.: Cisplatin enhances the antitumor effect of tumor necrosis factor-related apoptosis-inducing ligand gene therapy via recruitment of the mitochondria-dependent death signaling pathway. Cancer Gene Ther 2008, 15:356-370.

44. Panaretakis T, Laane E, Pokrovskaja K, Bjorklund AC, Moustakas A, Zhivotovsky B, Heyman M, Shoshan MC, Grander D: Doxorubicin requires the sequential activation of caspase-2, protein kinase Cdelta, and c-Jun $\mathrm{NH} 2$-terminal kinase to induce apoptosis. Mol Biol Cell 2005, 16:3821-3831.

45. Lassus $P$, Opitz-Araya X, Lazebnik Y: Requirement for caspase-2 in stressinduced apoptosis before mitochondrial permeabilization. Science 2002, 297:1352-1354

46. Wieder T, Essmann F, Prokop A, Schmelz K, Schulze-Osthoff K, Beyaert R, Dorken B, Daniel PT: Activation of caspase-8 in drug-induced apoptosis of B-lymphoid cells is independent of CD95/Fas receptor-ligand interaction and occurs downstream of caspase-3. Blood 2001 97:1378-1387

47. Engels $I H$, Stepczynska A, Stroh C, Lauber K, Berg C, Schwenzer R, Wajant $H$, Janicke RU, Porter AG, Belka C, et al.: Caspase-8/FLICE functions as an executioner caspase in anticancer drug-induced apoptosis. Oncogene 2000, 19:4563-4573.
48. Inoue S, Browne G, Melino G, Cohen GM: Ordering of caspases in cells undergoing apoptosis by the intrinsic pathway. Cell Death Differ 2009, 16:1053-1061.

doi: 10.1186/1476-4598-9-87

Cite this article as: Vaculova et al., Doxorubicin and etoposide sensitize small cell lung carcinoma cells expressing caspase-8 to TRAIL Molecular Cancer 2010, 9:87

\section{Submit your next manuscript to BioMed Central and take full advantage of:}

- Convenient online submission

- Thorough peer review

- No space constraints or color figure charges

- Immediate publication on acceptance

- Inclusion in PubMed, CAS, Scopus and Google Scholar

- Research which is freely available for redistribution

Submit your manuscript at www.biomedcentral.com/submit
C Biomed Central 